\title{
Characterization of the Casein Gene Complex in West African Goats and Description of a New $\alpha_{s 1}$-Casein Polymorphism
}

\author{
A. Caroli, ${ }^{\star 1}$ F. Chiatti, $\uparrow$ S. Chessa, $†$ D. Rignanese, $†$ E. M. Ibeagha-Awemu, $¥ \S$ and G. Erhardt§ \\ *Dipartimento di Scienze Biomediche e Biotecnologie, Università degli Studi di Brescia, Viale Europa 11, 25123 Brescia, Italy \\ †Dipartimento di Scienze e Tecnologie Veterinarie per la Sicurezza Alimentare, Università degli Studi di Milano, Via Trentacoste 2, \\ 20134 Milano, Italy \\ ‡Department of Animal Science, McGill University, Ste-Anne-De-Bellevue, Quebec, H9X 3V9, Canada \\ §Institut für Tierzucht und Haustiergenetik, Justus-Liebig Universität, Ludwigstr. 21 b, 35390 Gießen, Germany
}

\begin{abstract}
The analysis of casein polymorphisms was carried out in West Africa goat populations: Red Sokoto $(\mathrm{n}=$ 57), West African Dwarf Nigeria $(\mathrm{n}=27)$, West African Dwarf Cameroon $(\mathrm{n}=39)$, and Borno $(\mathrm{n}=37)$. The 4 casein genes $\alpha_{\mathrm{s} 1}$ (CSN1S1), $\beta$ (CSN2), $\alpha_{\mathrm{s} 2}(C S N 1 S 2)$, and $\kappa(C S N 3)$ were typed at the DNA level. No null alleles were found in any of the genes analyzed. A PCR single-strand conformation polymorphism method was implemented for the identification of $C S N 1 S 1^{*} F$ allele simultaneously with $A / O_{1}, B / E, N$ and the new allele. The allele differed from $C S N 1 S 1^{*} B$ by a synonymous transversion TCG $\rightarrow$ TCT in the codon corresponding to Ser $_{66}$ of the mature protein. The new allele, named $C S N 1 S 1^{*} B^{\prime}$, occurred at a high frequency in all the populations, ranging from 0.295 (West African Dwarf Cameroon) to 0.405 (Borno). A greater frequency was found for alleles associated with high $\alpha_{\mathrm{s} 1}$-casein quantity, as has already been observed in the goat populations from the Mediterranean area. The intermediate $E$ allele occurred only in the Red Sokoto and at a low frequency. The faint $F$ allele occurred in 3 populations at frequencies lower than 0.03. Linkage disequilibrium occurred in all the populations, with highly significant differences in Borno, Red Sokoto, and West Africa Dwarf Nigeria, and significant differences in West Africa Dwarf Cameroon. Only 10 haplotypes showed frequencies $\geq 0.05$ in at least 1 of the 4 populations considered, and the overall frequency was $>0.1$ only for 4 haplotypes: $B A A B, B^{\prime} A C A, A C A B$, and $B A C A$ (in the order CSN1S1-CSN2-CSN1S2-CSN3). Haplotype $B A A B$, postulated as an ancestral haplotype in previous studies, was the most common haplotype in all breeds except Borno, where $B^{\prime} A C A$ was predominant. The results obtained are of considerable significance given
\end{abstract}

Received October 15, 2006.

Accepted January 8, 2007.

${ }^{1}$ Corresponding author: caroli@med.unibs.it that very little information exists on the subject for African goats. The high frequency of strong alleles in the calcium-sensitive caseins as well as the high linkage disequilibrium found among the casein genes in the African breeds analyzed may suggest that specific casein haplotypes have already been selected due to their advantages for nutrition. Haplotypes providing greater protein and casein content would increase the energy content of milk, thus resulting in more favorable growth and survival of young goats and humans consuming the milk.

Key words: casein complex, West Africa, goat, $\alpha_{\mathrm{s} 1^{-}}$ casein

\section{INTRODUCTION}

Because the $\mathrm{CN}$ genes are tightly linked on the same chromosome (Ferretti et al., 1990; Threadgill and Womack, 1990), they are usually inherited as a gene complex, or haplotype, from parents to progeny. The entire CN gene complex spans about $250 \mathrm{~kb}$ on chromosome 6 in cattle, sheep, and goats (Hayes et al., 1993; Popescu et al., 1996).

Within the goat $\mathrm{CN}$ cluster, high polymorphism has been found at the 4 genes CSN1S1, CSN2, CSN1S2, and CSN3 coding respectively for the proteins $\alpha_{\mathrm{s} 1}-\mathrm{CN}$, $\beta-\mathrm{CN}, \alpha_{\mathrm{s} 2}-\mathrm{CN}$, and $\kappa-\mathrm{CN}$. Several alleles of the 3 calcium-sensitive $\mathrm{CN}\left(\alpha_{\mathrm{s} 1}-\mathrm{CN}, \beta-\mathrm{CN}\right.$, and $\left.\alpha_{\mathrm{s} 2}-\mathrm{CN}\right)$ are associated with a null or reduced expression of the specific protein.

Strong alleles $\left(A, B_{1}, B_{2}, B_{3}, B_{4}, C, H, L\right.$, and $\left.M\right)$, intermediate alleles ( $E$ and $I$ ), weak alleles ( $F$ and $G$ ), and null alleles $\left(O_{1}, O_{2}\right.$, and $\left.N\right)$ were described in $\alpha_{\mathrm{s} 1^{-}}$ CN (reviewed in Grosclaude and Martin, 1997; Rando et al., 2000; Ramunno et al., 2005).

At CSN2, 3 variants were associated with a normal $\beta$-CN content: $A, B$ (Mahé and Grosclaude, 1993), and $C$ (Neveu et al., 2002), and 2 null CSN2 alleles were identified (Ramunno et al., 1995; Persuy et al., 1999), and named respectively as $C S N 2{ }^{*} 0^{\prime}$ and $C S N 2 * 0$ by Neveu et al. (2002). Two CSN2 alleles have recently 
been identified: $C S N 2 * A 1$, which was defined as a synonymous mutation of $C S N 2 * A$ (Cosenza et al., 2005), and $C S N 2 * E$, which is characterized by a transversion TCT $\rightarrow$ TAT responsible for the AA substitution $\mathrm{Ser}_{166} \rightarrow \overline{\mathrm{Tyr}}_{166}$ in the mature protein (Caroli et al., 2006). Data about the expression of $C S N 2 * A 1$ and $C S N 2 * E$ are not yet available.

The $A, B$ (Boulanger et al., 1984), $C$ (Bouniol et al., 1994), $E$ (Lagonigro et al., 2001), and $F$ (Ramunno et al., 2001a)CSN1S2 alleles are associated with a normal $\alpha_{\mathrm{s} 2}$-CN synthesis level, whereas $D$ and 0 are associated with lower and null synthesis levels, respectively (Ramunno et al., 2001a,b).

Of the $16 C S N 3$ alleles identified and characterized in recent years (Caroli et al., 2001; Yahyaoui et al., 2001; Angiolillo et al., 2002; Yahyaoui et al., 2003; Jann et al., 2004; Prinzenberg et al., 2005), 13 are protein variants (named in alphabetical order from $A$ to $M$ ) and $3\left(B^{\prime}, B^{\prime \prime}, C^{\prime}\right)$ show silent mutations; their occurrence is detectable at the DNA level only.

Great differences have been found among goat breeds and populations in the polymorphism distribution within CN genes (Grosclaude et al., 1994; Caroli et al., 2001) and haplotypes (Sacchi et al., 2005; Caroli et al., 2006). The haplotype coding for $C S N 1 S 1 * B, C S N 2 * A$, $C S N 1 S 2 * A$, and $C S N 3 * B$ protein variants was postulated as ancestral among the haplotypes considered by Caroli et al. (2006).

European goat breeds have been thoroughly investigated, but data are missing regarding the $\mathrm{CN}$ gene and haplotype variation in goats from African countries. Such information could be of great interest, not only for utilization in animal breeding, but also from a phylogenetic point of view. This paper aimed to analyze the variability of the goat $\mathrm{CN}$ complex in 4 West Africa goat populations. A new CSN1S1 variant was also identified and characterized.

\section{MATERIALS AND METHODS}

\section{Samples and Breeds}

Blood samples were collected from the following West Africa goat populations: Red Sokoto $(n=57)$, West African Dwarf Nigeria $(\mathrm{n}=27)$, West African Dwarf Cameroon $(\mathrm{n}=39)$, and Borno ( $\mathrm{n}=37)$.

Red Sokoto Goat. The Red Sokoto goat, also known as Kano Brown or Maradi, is the most widely distributed goat breed in Nigeria. Spread over the northern two-thirds of the country, it accounts for about $60 \%$ of the Nigerian goat population, estimated at about 28 million animals (FAOSTAT, 2005). This breed is also found in southern Niger and northern Cameroon. It is a relatively small goat with an adult height at the withers of about $64 \mathrm{~cm}, \mathrm{BW}$ of about $27 \mathrm{~kg}$, a typical dark red or brown coat color, short and horizontal ears, and horns in both sexes (FDLPCS, 1992). Its main products include meat, milk, and hides. The skin is one of the world's most valuable (Devendra and McLeroy, 1982; FDLPCS, 1992). With an average milk yield per lactation of $46 \mathrm{~kg}$ (FDLPCS, 1992) and litter size at birth of 1.8 kids (Awemu et al., 1999), the Red Sokoto goat is one of the most prolific breeds of goats in the West African region. The milk of the Red Sokoto goat has high percentages of fat (5.8\%), total solids (15.37\%), and ash (0.77\%; Malau-Aduli and Anlade, 2002).

West African Dwarf Goat. Other names for the West African Dwarf(WAD) goat include African Dwarf, African Pygmy, Djallonke, Forest Goat, Fouta Djallon, Grassland Dwarf, Chèvre Naine de Savanes, Guinean, Guinean Dwarf, Ghana Dwarf, Congo Dwarf, Pygmy, Tibetana, Cameroon Dwarf, Chèvre de Casamance, Diougry, Chèvre Naine de l'Est, Kosi, and Nigerian Dwarf. The WAD goat is an achondroplastic dwarf animal that is widely distributed along the West African coastline and Central Africa. It constitutes about $50 \%$ of all goat breeds in Cameroon and is the second largest goat population in Nigeria (FDLPCS, 1992; Messine et al., 1995). The major characteristics include a height of 30 to 50 $\mathrm{cm}$, male adult weight of 20 to $25 \mathrm{~kg}$, multicolored coat, and horns in both sexes. Even though the main use of the breed is meat, recent investigations have shown that it has the same milk-producing ability as the Red Sokoto goat (Bemji, 2003). It is considered to be an up-and-coming dairy breed due to its promising milk production characteristics such as high butterfat and protein percentage (Wetherbee, 2002; Ruminations, 2007). The WAD goat is also reputed to be trypanotolerant (Agyemang, 2005). In this work, the WAD goat was sampled both in Nigeria and in Cameroon. We decided to take into account the different geographic origin of the WAD animals to highlight eventual differences between the 2 populations.

Borno. The Borno goat is found exclusively in Bornu and surrounding states in Nigeria. Another name is Bornu White goat, as it is a predominantly white animal, thought to have originated from the Sahel (also known as Desert or West African long-legged goat) or the Nigerian goat (FAO, 2006) breeds. It is intermediate in size between the Red Sokoto goat and the Sahel goat. Horns are present in both males and females. Its purposes include meat, milk, and a source of cultural savings. It is less well studied than the Red Sokoto and WAD breeds.

\section{Genotyping}

As described by Caroli et al. (2006), DNA was extracted from blood samples by standard methods, and 
typed. In addition, CSN1S2 was typed by PCR-RFLP according to Ramunno et al. (1999) to identify the $A$, $B$, and $C$ alleles at the DNA level. Moreover, CSN2 was typed by PCR-RFLP (Cosenza et al., 2005) to check the occurrence of the $A 1$ mutation.

A PCR-single strand conformation polymorphism (PCR-SSCP) method was implemented as an alternative to the PCR-RFLP method described for the identification of $C S N 1 S 1 * F$ allele (Ramunno et al., 2000). A 212- to 223-bp CSN1S1 fragment containing exon 9 was amplified by PCR performed in a $25-\mu \mathrm{L}$ reaction mixture containing $2 \mu \mathrm{L}$ of DNA solution (100 to 150 ng), $10 \mathrm{pmol}$ of each primer, and $1 \times$ PCR Master Mix (Fermentas, Vilnius, Lithuania). Primers were $5^{\prime}$-TTC TAA AAG TCT CAG AGG CAG-3' and 5'-GGG TTG ATA GCC TTG TAT GT-3'. The following amplification conditions were used: an initial denaturation step of $94^{\circ} \mathrm{C}$ for 5 min was followed by 35 cycles of $94^{\circ} \mathrm{C}$ for 40 $\mathrm{s}, 56^{\circ} \mathrm{C}$ for $40 \mathrm{~s}$, and $72^{\circ} \mathrm{C}$ for $90 \mathrm{~min}$, concluding with a final extension step of $72^{\circ} \mathrm{C}$ for 7 min using a PTC200 DNA Engine thermal cycler (MJ Research Inc., Waltham, MA).

For SSCP, $6 \mu \mathrm{L}$ of PCR product was added to $8 \mu \mathrm{L}$ of denaturing solution $(0.05 \%$ xylene-cyanol, $0.05 \%$ bromophenol blue, $0.02 M$ EDTA in deionized formamide). After heat denaturation of $95^{\circ} \mathrm{C}$ for $8 \mathrm{~min}$, the samples were immediately chilled on ice and then run overnight $(17 \mathrm{~h})$ on $12.5 \%$ acrylamide:bisacrylamide gels (37.5:1) with $1 \%$ glycerol in $0.5 \times$ Tris-borate-EDTA buffer $(0.54 \%$ Tris, $0.27 \%$ boric acid, $0.037 \%$ EDTA) at $240 \mathrm{~V}$ and $5^{\circ} \mathrm{C}$ (Penguin Dual Gel Water-Cooled Electrophoresis System, OWL Scientific Inc., Woburn, MA). Bands were visualized by silver staining (Bassam et al., 1991).

Reference samples carrying different CSN1S1 alleles $\left(C S N 1 S 1 * A, \quad C S N 1 S 1 * B, \quad C S N 1 S 1 * F, \quad C S N 1 S 1{ }^{*} E\right.$, $C S N 1 S 1 * 0_{1}, C S N 1 S 1 * N$ ) were used to validate the method. Moreover, 40 samples of the present work analyzed by the SSCP method described here were randomly chosen and typed also by PCR-RFLP (Ramunno et al., 2000) as a further validation test. Allele-specific PCR analyses were necessary to distinguish $C S N 1 S 1{ }^{*} B$ from $C S N 1 S 1^{*} E$ (Jànsa Pérez et al., 1994) and CSN1S1*A from $C S N 1 S 1{ }^{*} 0_{1}$ (Cosenza et al., 2003), both after PCR-SSCP and PCR-RFLP genotyping of CSN1S1*F.

The DNA samples showing previously uncharacterized patterns on SSCP gels during CSN1S1 typing were randomly selected for sequencing. Four samples were sequenced, 1 homozygous and 3 heterozygous. Primers used for sequencing were the same used for the PCRSSCP technique. The PCR products were sequenced by PRIMM Srl (Milan, Italy). The nucleotide sequences and the deduced AA sequences were analyzed by Bioedit software (Hall, 1999).

\section{Statistical Analyses}

The GENEPOP program (Raymond and Rousset, 1995) was used for the evaluation of allele frequencies and deviations from Hardy-Weinberg equilibrium. The $\mathrm{CN}$ haplotype frequencies were estimated by the $\mathrm{EH}$ program (Xie and Ott, 1993). For EH computation, alleles with frequencies lower than 0.05 were ignored.

\section{RESULTS AND DISCUSSION}

\section{A New CSN1S1 Allele}

The PCR-SSCP developed for the analysis of CSN1S1 allowed the simultaneous identification of the alleles $C S N 1 S 1 * F, \quad C S N 1 S 1 * A / 0_{1}, \quad C S N 1 S 1 * B / E$, and $C S N 1 S 1^{*} N$, which can also be discriminated by PCRRFLP (Ramunno et al., 2000), as well as identification of an unknown mutation involving several samples, which was defined as $C S N 1 S 1 * B$ by the standard DNA methods (Jànsa Pérez et al., 1994; Ramunno et al., 2000; Figure 1). The new allele was named $C S N 1 S 1^{*} B^{\prime}$. It was characterized by a synonymous transversion TCG $\rightarrow$ TCT in the Ser $_{66}$ of the mature protein. As to the possible origin of this mutation in the CN complex evolution, the alignment among the CSN1S1 sequences of different species (bovine: GenBank accession number X59856; ovine: NM_001009795, X03237; caprine: AJ504710, AJ504711, AJ504712) suggests that $C S N 1 S 1{ }^{*} B^{\prime}$ arises from the goat ancestral $C S N 1 S 1^{*} B$ allele. In fact, guanine occurs instead of thymine in the corresponding nucleotide position in the sequences of all these species.

\section{Allele Variability}

Table 1 shows the allele frequencies at each $\mathrm{CN}$ gene. Hardy-Weinberg equilibrium occurred in all loci of the 4 populations, except for a deviation $(P=0.053)$ at CSN1S1 in Borno goat where an excess of homozygous animals was found (18 observed vs. 12.4 expected).

No null alleles occurred in any of the calcium-sensitive genes analyzed, whereas strong alleles were found at very high frequencies in all of them. This is a useful indication for selection programs to improve milk traits, mainly focusing on composition properties and direct consumption quality.

At CSN1S1, a greater frequency was found for alleles associated with high $\alpha_{\mathrm{s} 1}$-CN quantity, as has already been observed in the goat populations from the Mediterranean area (Grosclaude and Martin, 1997; Tadlaoui Ouafi et al., 2002; Sacchi et al., 2005). The intermediate $E$ allele occurred only in the Red Sokoto and at a low frequency. The faint $F$ allele occurred in 3 populations, at frequencies lower than 0.03 . 


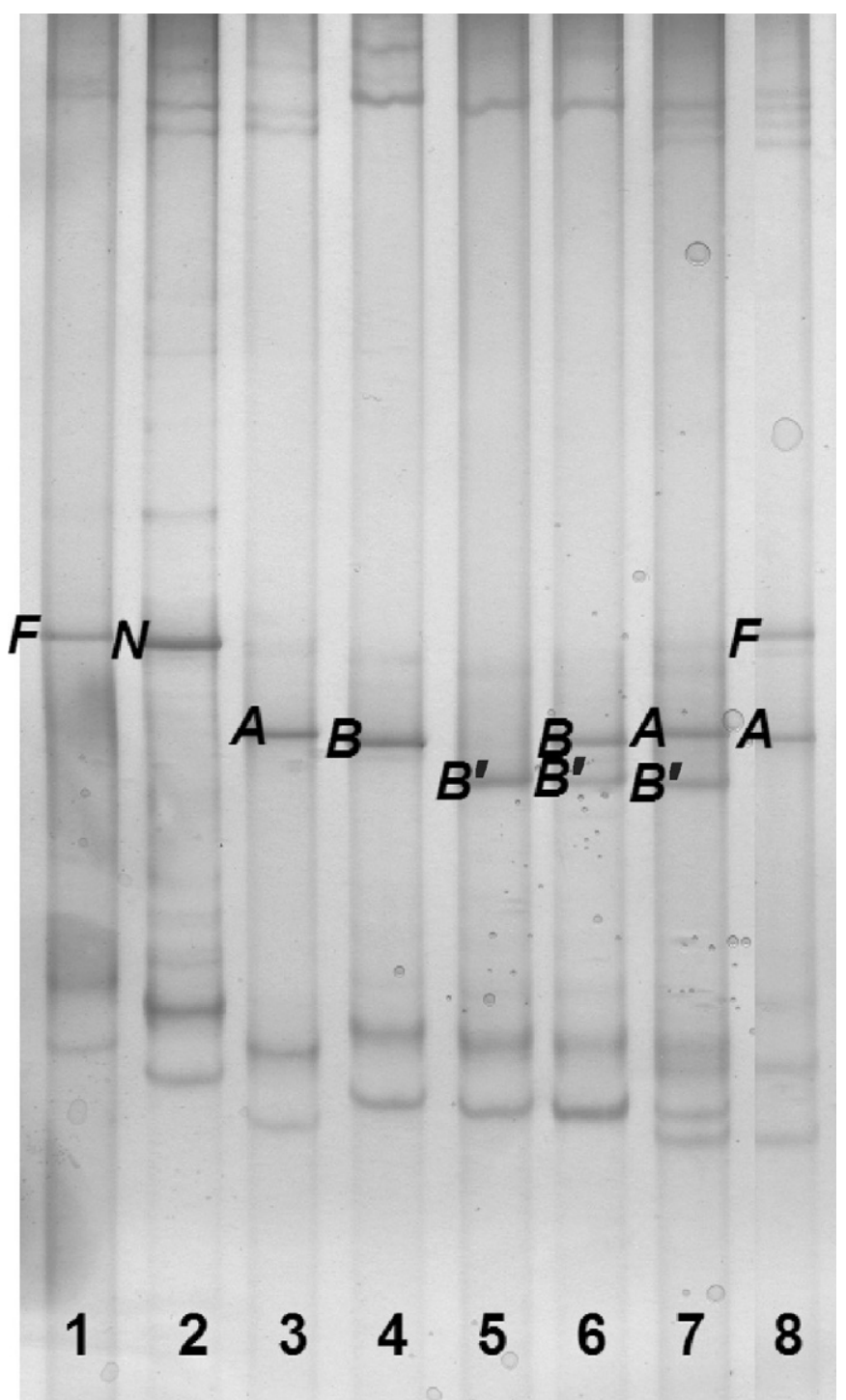

Figure 1. Analysis by PCR-single strand conformational polymorphism of goat CSN1S1. The discriminating band of each allele is indicated. In ascending migration mobility: $F=C S N 1 S 1 * F ; N=$ CSN1S1*N;A $=$ CSN1S1*A + CSN1S1*0 $0_{1} ; B=C S N 1 S 1 * B+$ $C S N 1 S 1 * E ; B^{\prime}=C S N 1 S 1 * B^{\prime}$. The genotypes of the 8 samples are 1) $F F$, 2) $N N$, 3) $A A$, 4) $B B$, 5) $B^{\prime} B^{\prime}$, 6) $B B^{\prime}$, 7) $A B^{\prime}$, and 8) $A F$. The discrimination of $A$ and $B$ alleles respectively from 0 and $E$ was performed successively by allele-specific PCR (Jànsa Pérez et al., 1994; Cosenza et al., 2003).

The most common CSN1S1 allele was $B$. The new $\operatorname{CSN} 1 S 1^{*} B^{\prime}$ allele also occurred at a high frequency in all the populations. The $A$ allele was the third most common allele in all populations.

As far as CSN2 is concerned, the $A$ allele was by far the most common, with a frequency exceeding 0.7 in all the populations. Only $C S N 2 * C$ was found as an alternative to $C S N 2 * A$, except for in a Red Sokoto goat carrying an $A 1$ allele in an $A 1 C$ genotype. This sample was defined as $C C$ by PCR-SCCP analysis (Chessa et al., 2005a). Most probably, the synonymous mutation found by Cosenza et al. (2005) involves both $C S N 2 * A$ and $C S N 2 * C$. In this case, we should name the allele as $C S N 2 * C 1$ instead of $C S N 2 * A 1$. Due to the low frequency of the synonymous mutation in the populations analyzed, the nomenclature proposed by Cosenza et al. (2005) has been maintained, waiting for further investigations in different breeds.

The predominant CSN1S2 variant was $A$, followed by $C$. The $B$ and $F$ alleles were absent or rare in these breeds.

Also, CSN3 may be considered biallelic for $A$ and $B$; the $M$ allele was observed only in the Red Sokoto, and at a low frequency. The $A$ and $B$ frequencies were similar, with higher values for $C S N 3 * B$ except in Borno. In European breeds, $C S N 3^{*} B$ is usually the highly prevalent allele (Yahyaoui et al., 2003; Prinzenberg et al., 2005; Sacchi et al., 2005; Caroli et al., 2006).

A clear predominance of the proposed goat ancestral alleles CSN1S1*B (Grosclaude et al., 1994), CSN2*A (Chessa et al., 2005a), and CSN1S2*A (Sacchi et al., 2005 ) is noticeable, whereas mutated variants at the calcium-sensitive $\mathrm{CN}$ are usually most common in the European goat breeds; that is, $C S N 1 S 1{ }^{*} F, C S N 2{ }^{*} C$, and $C S N 1 S 2 * F$ (Caroli et al., 2006).

Significant differences in allele frequencies between the $2 \mathrm{WAD}$ populations were found for all the alleles except for the novel $C S N 1 S 1^{*} B^{\prime}$ variant. This discrepancy linked to the geographic origin of the samples was also confirmed at the haplotype level (Table 2) and may be the consequence of genetic drift.

\section{Haplotype Distribution}

Haplotype frequencies at the CSN1S1-CSN2CSN1S2-CSN3 cluster are reported in Table 2. A total of 24 possible haplotypes resulted from the combination of 3-2-2-2 alleles considered. The haplotype frequencies expected under the independence hypothesis (IF) were strongly different from the haplotype frequencies estimated by the $\mathrm{EH}$ program taking association into account (AF).

Only 10 haplotypes showed AF values $\geq 0.05$ in at least 1 of the 4 populations considered, and the overall $\mathrm{AF}$ frequency was $>0.1$ only in 4 of them: $B A A B, B^{\prime} A C A$, $A C A B$, and $B A C A$ (in the order: CSN1S1-CSN2$C S N 1 S 2-C S N 3)$. A high frequency of the $B A A B$ haplotype, postulated as ancestral in previous studies (Sacchi et al., 2005; Caroli et al., 2006), was observed in all the populations. It was the most common haplotype in all breeds except Borno, where $B^{\prime} A C A$ was predominant ( $\mathrm{AF}=0.25)$, followed by $A C A B$ (0.159), $B A A A$ (0.157), and $B A A B(0.123)$. 
Table 1. Allele frequencies at the casein loci in Borno (BG), Red Sokoto (RS), West African Dwarf Cameroon (WADC), and West African Dwarf Nigeria (WADN) breeds

\begin{tabular}{|c|c|c|c|c|c|}
\hline \multirow[b]{2}{*}{ Locus } & \multirow[b]{2}{*}{ Allele } & \multicolumn{4}{|c|}{ Breed } \\
\hline & & $\begin{array}{c}\text { BG } \\
(\mathrm{n}=37)\end{array}$ & $\begin{array}{c}\mathrm{RS} \\
(\mathrm{n}=57)\end{array}$ & $\begin{array}{l}\text { WADC } \\
(\mathrm{n}=39)\end{array}$ & $\begin{array}{r}\text { WADN } \\
(\mathrm{n}=27)\end{array}$ \\
\hline \multirow[t]{5}{*}{ CSN1S1 } & A & 0.189 & 0.175 & 0.077 & 0.259 \\
\hline & $B$ & 0.378 & 0.482 & 0.615 & 0.444 \\
\hline & $B^{\prime}$ & 0.405 & 0.316 & 0.295 & 0.296 \\
\hline & $E$ & $-^{1}$ & 0.018 & - & - \\
\hline & $F$ & 0.027 & 0.009 & 0.013 & - \\
\hline \multirow[t]{3}{*}{ CSN2 } & $A$ & 0.703 & 0.746 & 0.833 & 0.722 \\
\hline & $A 1$ & - & 0.009 & - & - \\
\hline & $C$ & 0.297 & 0.245 & 0.167 & 0.278 \\
\hline \multirow[t]{4}{*}{ CSN1S2 } & $A$ & 0.55 & 0.596 & 0.590 & 0.759 \\
\hline & $B$ & - & 0.026 & - & - \\
\hline & $C$ & 0.446 & 0.368 & 0.397 & 0.241 \\
\hline & $F$ & - & 0.009 & 0.013 & - \\
\hline \multirow[t]{3}{*}{ CSN3 } & $A$ & 0.514 & 0.412 & 0.311 & 0.407 \\
\hline & $B$ & 0.486 & 0.570 & 0.689 & 0.593 \\
\hline & $M$ & - & 0.018 & - & - \\
\hline
\end{tabular}

\footnotetext{
1 indicates allele frequency $=0$.
}

Table 2. Haplotype frequencies at the casein loci in Borno (BG), Red Sokoto (RS), West African Dwarf Cameroon (WADC), and West African Dwarf Nigeria (WADN) breeds ${ }^{1}$

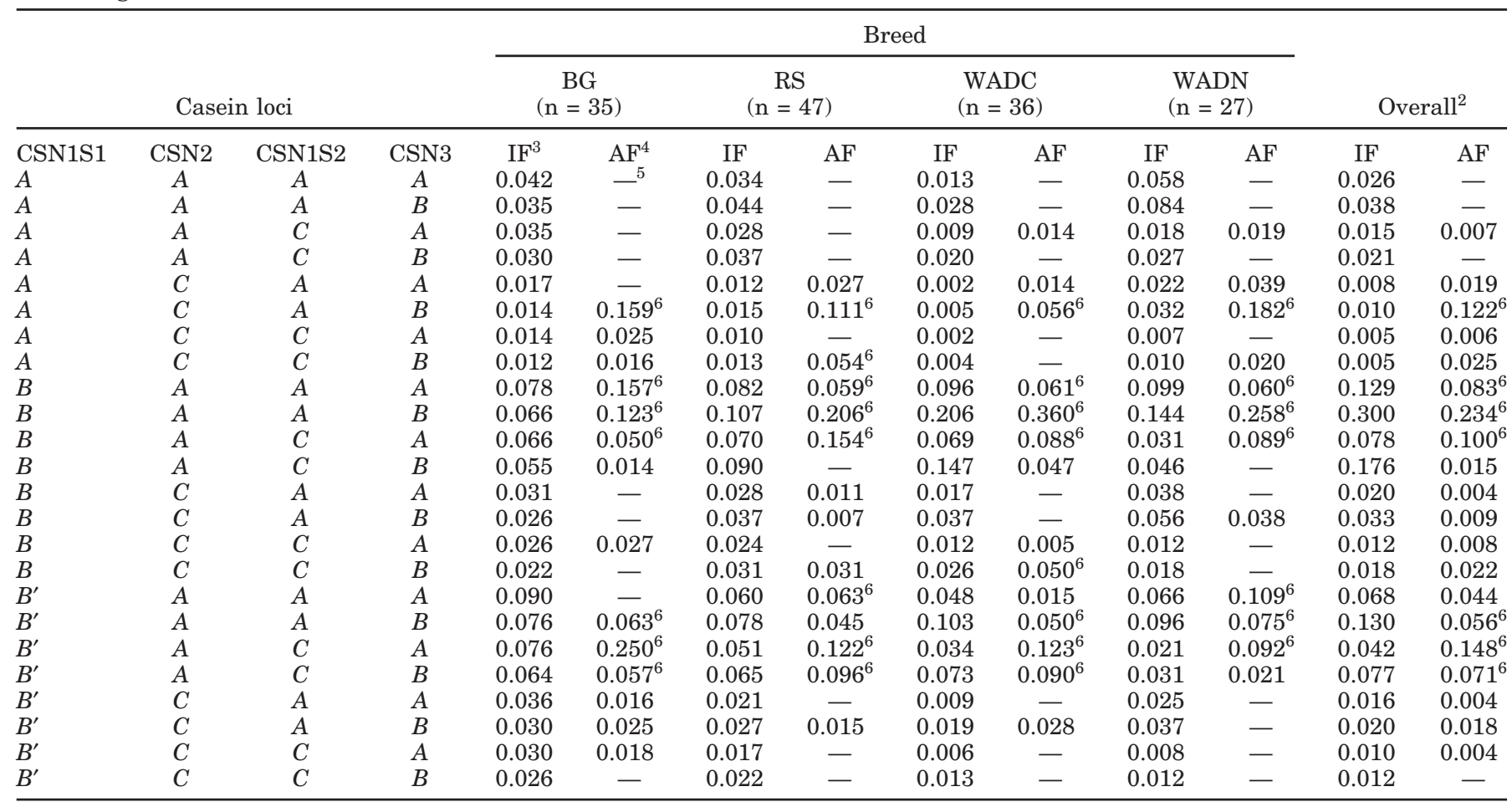

${ }^{1}$ Frequencies were estimated by EH program, not considering allele frequencies lower than 0.05 .

${ }^{2}$ Overall $=$ average frequencies across sampled animals.

${ }^{3} \mathrm{IF}=$ haplotype frequencies expected under the independence hypothesis.

${ }^{4} \mathrm{AF}=$ haplotype frequencies estimated taking association into account.

5 _ indicates haplotype frequencies $<0.001$.

${ }^{6}$ Indicates $\mathrm{AF} \geq 0.05$ in at least one population. 


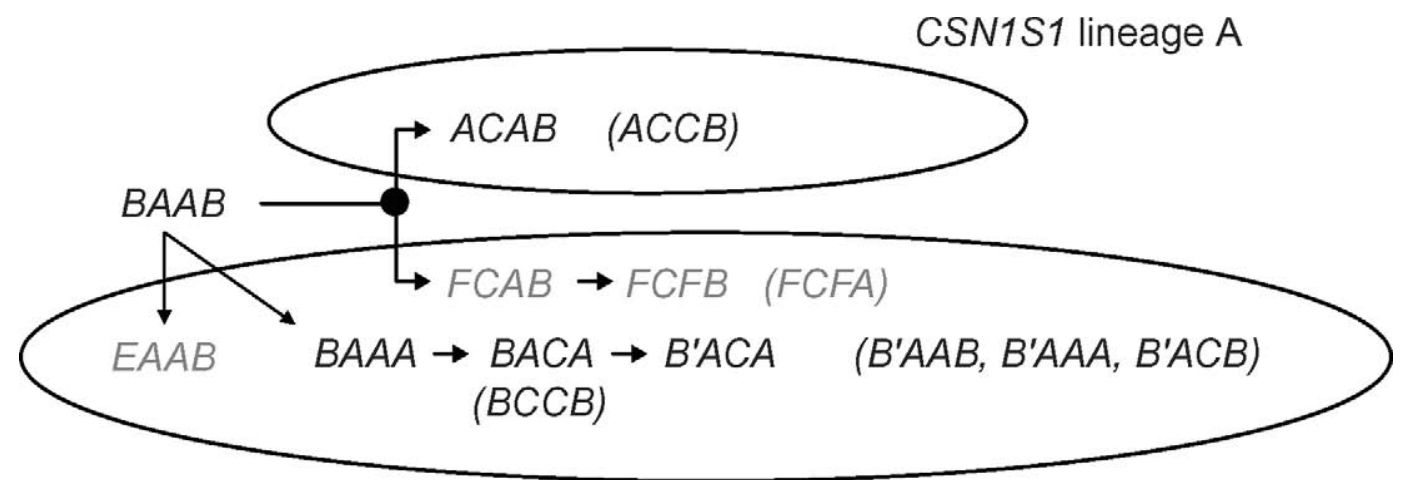

CSN1S1 lineage B

Figure 2. Possible evolution of the casein haplotype. Haplotypes from Caroli et al. (2006) are shown in gray; recombinant haplotypes are given in parentheses. The black dot indicates the probable mutation event leading to the $C S N 2{ }^{*} C$ allele and to the haplotype $B C A B$.

Linkage disequilibrium occurred in all the populations, with highly significant differences between $\mathrm{AF}$ and $\operatorname{IF}(P<0.001)$ in Borno ( $\chi^{2}$ value of 80.95 , associated with $23 \mathrm{df})$, Red Sokoto $\left(\chi_{[23]}^{2}=66.71\right)$, WAD Nigeria $\left(\chi_{[23]}^{2}=55.85\right)$, and significant differences $(P<0.05)$ in WAD Cameroon $\left(\chi_{[23]}^{2}=35.27\right)$. Haplotypes $A C A B$, $B A A B, B^{\prime} A C A$ had much greater AF than IF (Table 2). The opposite was true for haplotypes $B A C B, A A A B$, and $A A A A$.

For CSN2, the $A$ allele was most often associated with $C S N 1 S 1^{*} B$ and $C S N 1 S 1^{*} B^{\prime}$ and was almost never linked to $\operatorname{CSN} 1 S 1 * A$ (Table 2). The opposite situation occurred for $C S N 2 * C$, which was usually associated with $C S N 1 S 1 * A$, even if the frequencies of $C S N 1 S 1 * B$ CSN1S1* $B^{\prime}-C S N 2 * C$ combinations were slightly higher than $C S N 1 S 1 * A-C S N 2 * A$. This finding might indicate that the differentiation from $C S N 2 * A$ to $C S N 2 * C$ occurred before the evolution of $C S N 1 S 1{ }^{*} B$ into the numerous mutations affecting the CSN1S1 locus. This result in West African goats is in agreement with Chessa et al. (2005b) and Caroli et al. (2006). In particular, the $C S N 2 * A$ to $C S N 2 * C$ differentiation might have arisen before the splitting of CSN1S1 in the 2 lineages (A and B) proposed by Grosclaude et al. (1994). This hypothesis is shown in Figure 2 where a possible evolution is given for the 10 most common haplotypes of the present work, together with other haplotypes considered by Caroli et al. (2006). The haplotype $B C A B$, in which the $C S N 2 * C$ mutation event arose most probably before the CSN1S1 splitting, is not indicated in Figure 2 because it occurred at a rather low frequency in the 4 populations, whereas the possible recombinant $B C C B$ haplotype was more common (Table 2).

The haplotype FCFA was common in the northern Italian breeds considered by Caroli et al. (2006) who included it in the proposed phylogeny as a parental haplotype, even if the $C S N 3 * A$ leading mutation was suggested as possible also in CSN1S1 lineage A, leading to the ACAA haplotype. However, the $F-F A$ haplotype (the line indicates $C S N 2 * A+C S N 2 * C$ ) was found in southern Italian breeds at a rather low frequency (Sacchi et al., 2005), and F-FB (named as F-FD due to the different CSN3 nomenclature used) was the most common haplotype, with $\mathrm{AF}$ values much higher than IF values. Thus, it can be expected that the high frequency of FCFA in Northern Italian populations may be the consequence of a recombinant event in the $\mathrm{CN}$ haplotype, which was largely spread in the populations due to either genetic drift or, more intriguingly, to a superior fitness of animals with this haplotype in the specific breeding conditions.

In all cases, it is most probable that the mutation leading to $C S N 3^{*} A$ occurred neither from $C S N 1 S 1^{*} A$ nor $C S N 1 S 1^{*} F$, but from $C S N 1 S 1 * B$-carrying haplotypes. The only difference between $C S N 3^{*} B$ and $\operatorname{CSN}^{*} A$ is the AA substitution Ile to Val at position 119 of the mature protein, which is located in CN glycomacropeptide (Yahyaoui et al., 2001; Jann et al., 2004). The antithrombotic and antimicrobical properties of this peptide arising from the $\kappa$-CN cleavage by rennet in bovine milk are described (Meisel, 2005; Rhoades et al., 2005). The large diffusion of $\kappa$-CN $\mathrm{Ile}_{119}$ to $\mathrm{Val}_{119}$ substitution in different goat $\mathrm{CN}$ haplotypes might be considered in the light of particular biological properties of the $\mathrm{CN}$-glycomacropeptide genetic variants.

\section{CONCLUSIONS}

A new allele has been identified and characterized at the CSN1S1 gene that occurred in all the breeds. No null allele was found in any of the genes analyzed. A high frequency of the $\operatorname{CSN} 1 S 1 * B, C S N 2 * A, C S N 1 S 2 * A$, and $C S N 3 * B$ alleles, postulated as ancestral in previous 
studies, was found in all the populations. The findings suggest a relationship between African goat breeds and the breeds of southern Europe characterized by high frequencies of CSN1S1 strong alleles, whereas for the other calcium-sensitive $\mathrm{CN}$, clear differences were found in the predominant alleles with respect to European breeds. Interestingly, although $C S N 3{ }^{*} B$ is usually highly prevalent in $C S N 3^{*} A$ in European breeds, the $A$ and $B$ frequencies were more balanced in the African goats.

The CN variability in African goats allowed the inclusion of some haplotypes carrying the $C S N 1 S 1 * B$ allele and its synonymous variant, $B^{\prime}$, in the proposal of the CN haplotype phylogenesis. Genetic drift, as well as attractive fitness mechanisms, seems to have strongly influenced the $\mathrm{CN}$ haplotype structure in different goat breeds worldwide.

The high frequency of strong alleles in the calciumsensitive $\mathrm{CN}$ as well as the high linkage disequilibrium found among the $\mathrm{CN}$ genes in the African breeds analyzed may suggest that specific $\mathrm{CN}$ haplotypes have already been selected due to their advantages for nutrition. Haplotypes providing greater protein and $\mathrm{CN}$ content would increase the energy content of milk, thus resulting more favorable for growth and survival of young goats and humans consuming the milk.

\section{ACKNOWLEDGMENT}

We thank PRIN 2005 (2005075887_001) for partial financial support.

\section{REFERENCES}

Agyemang, K. 2005. Trypanotolerant livestock in the context of trypanosomiasis intervention strategies. PAAT Technical Information Series 7. FAO, Rome, Italy.

Angiolillo, A., M. H. Yahyaoui, A. Sanchez, F. Pilla, and J. M. Folch. 2002. Characterization of a new genetic variant in the caprine $\kappa$-casein gene. J. Dairy Sci. 85:2679-2680.

Awemu, E. M., L. N. Nwakalor, and B. Y. Abubakar. 1999. Environmental influences on preweaning mortality and reproductive performance of Red Sokoto does. Small Rumin. Res. 34:161-165.

Bassam, B. J., G. Caetano-Anolles, and P. M. Gresshoff. 1991. Fast and sensitive silver staining of DNA in polyacrylamide gels. Anal. Biochem. 196:80-83.

Bemji, M. N. 2003. Milk production and preweaning growth of West African Dwarf and Red Sokoyo goat. PhD thesis. University of Agriculture, Abeokuta, Nigeria.

Boulanger, A., F. Grosclaude, and M. F. Mahé. 1984. Polymorphisme des caséines $\alpha \mathrm{s} 1$ and $\alpha \mathrm{s} 2$ de la chèvre (Capra hircus). Genet. Sel. Evol. 16:157-176.

Bouniol, C., G. Brignon, M. F. Mahé, and C. Printz. 1994. Biochemical and genetic analysis of variant $\mathrm{C}$ of caprine $\alpha_{\mathrm{s} 2}$-casein. Anim. Genet. 25:173-177.

Caroli, A., F. Chiatti, S. Chessa, D. Rignanese, P. Bolla, and G. Pagnacco. 2006. Focusing on the goat casein gene complex. J. Dairy Sci. 89:3178-3187.

Caroli, A., O. Jann, E. Budelli, P. Bolla, S. Jäger, and G. Erhardt. 2001 . Genetic polymorphism of goat $\kappa$-casein (CSN3) in different breeds and characterization at DNA level. Anim. Genet. 32:226-230.
Chessa, S., E. Budelli, F. Chiatti, A. M. Cito, P. Bolla, and A. Caroli. 2005a. Predominance of $\beta$-casein (CSN2) $\mathrm{C}$ allele in goat breeds reared in Italy. J. Dairy Sci. 88:1878-1881.

Chessa, S., F. Chiatti, D. Rignanese, P. Bolla, and A. Caroli. 2005b. Casein haplotype variability in Apulian goat breeds. CD XIII Congresso Internazionale Federazione Mediterranea Sanità e Produzione Ruminanti, Valenzano, Bari, Italy.

Cosenza, G., R. Illario, A. Rando, P. Di Gregorio, P. Masina, and L. Ramunno. 2003. Molecular characterization of the goat CSN1S101 allele. J. Dairy Res. 70:237-240.

Cosenza, G., A. Pauciullo, D. Gallo, D. Di Berardino, and L. Ramunno. 2005. A SspI PCR-RFLP detecting a silent allele at the goat CSN2 locus. J. Dairy Res. 72:456-459.

Devendra, C., and G. B. McLeroy. 1982. Goat and Sheep Production in the Tropics. Longman, London, UK.

FAO. 2006. DAD-IS database. http://www.fao.org/dad-is/index.asp Accessed Dec. 15, 2006.

FAOSTAT. 2005. FAOSTAT data 2005. http://www.faostat.org/ Accessed Mar. 16, 2007.

FDLPCS (Federal Dept. Livestock and Pest Control Services). 1992. Nigerian Livestock Resources. Volume II. National Synthesis. FDLPCS, Abuja, Nigeria.

Ferretti, L., P. Leone, and V. Sgaramella. 1990. Long range restriction analysis of the bovine casein genes. Nucleic Acids Res. 18:6829-6833.

Grosclaude, F., and P. Martin. 1997. Casein polymorphisms in the goat. Pages 241-253 in Milk Protein Polymorphism. International Dairy Federation, Brussels, Belgium.

Grosclaude, F., G. Ricordeau, P. Martin, F. Remeuf, L. Vassal, and J. Bouillon. 1994. Du gène au fromage: Le polymorphisme de la caséine $\alpha_{\mathrm{s} 1}$ caprine, ses effets, son évolution. INRA Prod. Anim. 7:3-19.

Hall, T. A. 1999. BioEdit: A user-friendly biological sequence alignment editor and analysis program for Windows 95/98/NT. Nucleic Acids Symp. Ser. 41:95-98.

Hayes, H., E. Petit, C. Bouniol, and P. Popescu. 1993. Localisation of the alpha-S2-casein gene (CASAS2) to the homologous cattle, sheep and goat chromosome 4 by in situ hybridisation. Cytogenet. Cell Genet. 64:282-285.

Jann, O., E. M. Prinzenberg, G. Luikart, A. Caroli, and G. Erhardt. 2004. High polymorphism in the $\kappa$-casein (CSN3) gene from wild and domestic caprine species revealed by DNA sequencing. J. Dairy Res. 71:188-195.

Jànsa Pérez, M., C. Leroux, A. Sanchez Bonastre, and P. Martin. 1994. Occurrence of a LINE element in the 3'UTR of an allelic form of the goat alpha s1-casein gene associated with a reduced level of protein synthesis. Gene 147:179-187.

Lagonigro, R., E. Pietrola, M. D'Andrea, C. Veltri, and F. Pilla. 2001. Molecular genetic characterization of the goat s2-casein $\mathrm{E}$ allele. Anim. Genet. 32:391-393.

Mahé, M. F., and F. Grosclaude. 1993. Polymorphism of $\beta$-casein in the Creole goat of Guadeloupe, evidence for a null allele. Genet. Sel. Evol. 25:403-408.

Malau-Aduli, A. E. O., and Y. R. Anlade. 2002. Comparative study of milk composition of cattle, sheep and goats in Nigeria. Anim. Sci. J. 73:541-544.

Meisel, H. 2005. Biochemical properties of peptides encrypted in bovine milk proteins. Curr. Med. Chem. 12:1905-1919.

Messine, O., V. N. Tanya, D. A. Mbah, and C. L. Tawah. 1995. Ressources génétiques animales du Cameroun. Passé, présent et avenir: Le cas de ruminants. Anim. Genet. Resour. Inf. 16:51-69.

Neveu, C., D. Mollé, J. Moreno, P. Martin, and J. Léonid. 2002. Heterogeneity of caprine beta-casein elucidated by RP-HPLC/MS: Genetic variants and phosphorylation. J. Protein Chem. 21:557-567.

Persuy, M. A., C. Printz, J. F. Medrano, and J. C. Mercier. 1999. A single nucleotide deletion resulting in a premature stop codon is associated with marked reduction of transcripts from a goat $\beta$ casein null allele. Anim. Genet. 30:444.

Popescu, C. P., S. Long, P. Riggs, J. Womack, S. Schmutz, R. Fries, and D. S. Gallagher. 1996. Standardization of cattle karyotype 
nomenclature: Report of the committee for the standardization of the cattle karyotype. Cytogenet. Cell Genet. 74:259-261.

Prinzenberg, E. M., K. Gutscher, S. Chessa, A. Caroli, and G. Erhardt. 2005. Caprine $\kappa$-casein (CSN3) polymorphism: New developments of the molecular knowledge. J. Dairy Sci. 88:1490-1498.

Ramunno, L., G. Cosenza, M. Pappalardo, E. Longobardi, D. Gallo, N. Pastore, P. Di Gregorio, and A. Rando. 2001a. Characterization of two new alleles at the goat CSN1S2 locus. Anim. Genet. 32:264-268.

Ramunno, L., G. Cosenza, M. Pappalardo, N. Pastore, D. Gallo, P. Di Gregorio, and P. Masina. 2000. Identification of the goat CSN1S1F allele by means of PCR-RFLP method. Anim. Genet. 31:342.

Ramunno, L., G. Cosenza, A. Rando, A. Pauciullo, R. Illario, D. Gallo, D. Di Berardino, and P. Masina. 2005. Comparative analysis of gene sequence of goat CSN1S1 F and N alleles and characterization of CSN1S1 transcript variants in mammary gland. Gene 345:289-299.

Ramunno, L., E. Longobardi, G. Cosenza, P. Di Gregorio, A. Rando, and P. Masina. 1999. A PstI PCR-RFLP at the goat CSN1S2 gene. Anim. Genet. 30:242.

Ramunno, L., E. Longobardi, M. Pappalardo, A. Rando, P. Di Gregorio, G. Cosenza, P. Mariani, N. Pastore, and P. Masina. 2001b. An allele associated with a non detectable amount of alpha s2casein in goat milk. Anim. Genet. 32:19-26.

Ramunno, L., P. Mariani, M. Pappalardo, A. Rando, M. Capuano, P. Di Gregorio, and G. Cosenza. 1995. Un gene ad effetto maggiore sul contenuto di caseina $\beta$ nel latte di capra. Pages $185-186$ in Proc. XI Conv. ASPA, Grado, Italy.

Rando, A., L. Ramunno, and P. Masina. 2000. Mutations in casein genes. Zoot. Nutriz. Anim. 26:105-114.
Raymond, M., and F. Rousset. 1995. Genepop (version 1.2): Population genetics software for exact test and ecumenicism. J. Hered. 86:248-249.

Rhoades, J. R., G. R. Gibson, K. Formentin, M. Beer, N. Greenberg, and R. A. Rastal. 2005. Caseinoglycomacropeptide inhibits adhesion of pathogenic Escherichia coli strains to human cells in culture. J. Dairy Sci. 88:3455-3459.

Ruminations. 2007. The Nigerian Dwarf and Mini Dairy Goat Magazine. http://www.karmadillo.com/Ruminations Accessed Mar. 16, 2007.

Sacchi, P., S. Chessa, E. Budelli, P. Bolla, G. Ceriotti, D. Soglia, R. Rasero, E. Cauvin, and A. Caroli. 2005. Casein haplotype structure in five Italian goat breeds. J. Dairy Sci. 88:1561-1568.

Tadlaoui Ouafi, A., J.-M. Babilliot, C. Leroux, and P. Martin. 2002. Genetic diversity of the two main Moroccan goat breeds: Phylogenetic relationships with four breeds reared in France. Small Rumin. Res. 45:225-233.

Threadgill, D. W., and J. E. Womack. 1990. Genomic analysis of the major bovine milk proteins genes. Nucleic Acids Res. 18:69356942.

Wetherbee, K. 2002. Want Milk? Get Goats. Mother Earth News. Issue 192. http://www.motherearthnews.com/Livestock-andFarming/2002-06-01/Want-Milk-Get-Goats.aspx Accessed Mar. $18,2007$.

Xie, X., and J. Ott. 1993. Testing linkage disequilibrium between a disease gene and marker loci. Am. J. Hum. Genet. 53:1107.

Yahyaoui, M. H., A. Angiolillo, F. Pilla, A. Sanchez, and J. M. Folch. 2003. Characterization and genotyping of the caprine kappa casein variants. J. Dairy Sci. 86:2715-2720.

Yahyaoui, M. H., A. Coll, A. Sanchez, and J. M. Folch. 2001. Genetic polymorphism of the caprine kappa casein gene. J. Dairy Res. 68:209-216. 